\title{
Correction to: Scotland's Geomorphological Heritage and Its Conservation
}

John E. Gordon, Vanessa Brazier, James D. Hansom, and Alan Werritty

\section{Correction to:}

Chapter 29 in: C. K. Ballantyne and J. E. Gordon (eds.), Landscapes and Landforms of Scotland, World Geomorphological Landscapes, https://doi.org/10.1007/978-3-030-71246-4_29

The original version of the book was inadvertently published with error in "Neogene/Early Pleistocene fluvial gravels", and this has been corrected as "Palaeogene fluvial gravels" in Page "487" of Chapter "29".

The correction chapter and the book have been updated with change.

The updated version of this chapter can be found at https://doi.org/10.1007/978-3-030-71246-4_29 